\title{
Antiviral İlaçlar
}

\author{
Ali Küçük, Yakup Yıldırım \\ Mehmet Akif Ersoy Üniversitesi, Veteriner Fakültesi, Viroloji Anabilim Dall, Burdur
}

Geliş Tarihi / Received: 09.04.2019, Kabul Tarihi / Accepted: 14.05.2019

\begin{abstract}
Özet: Tarih boyunca viral hastalıklar epidemiler veya pandemiler meydana getirerek, insanoğlunu ve onunla etkileşim halinde olan tüm canlıların yaşamını tehdit etmiştir. Milyonlarca canlının ölümüne veya itlafına yol açan bu salgınlar, korunma ve tedavi gereksinimlerini de beraberlerinde getirmiştir. Yirminci yüzyılın başlarında gelişmeye başlayan teknoloji ve sağlık imkanları, viral hastalıkların sağaltımı üzerinde araştırmalar ve çalışmalar yapılmasına olanak sağlamıştır. Yapılan bu derlemede, insan ve hayvan sağlı̆̆ını tehdit eden viral enfeksiyonların tedavisinde kullanılmak amacıyla geliştirilen antiviral ajanlar hakkında bilgi verilmiştir.
\end{abstract}

Anahtar kelimeler: Antiviral ilaç, virüs

\section{Antiviral Drug}

\begin{abstract}
Throughout history, viral diseases have always threatened lives of all humans and living beings in contact with them causing epidemics and pandemics. These epidemics that caused death or destruction of millions of living beings also brought about the need for protection and treatment. Technological and health opportunities that started to develop at the beginning of the 20st century made it possible to convey studies and research on treatment of viral diseases. In this composition, information has been provided about antiviral agents developed to be used in treatment of viral infections threatening human and animal health.
\end{abstract}

Key words: Antiviral drug, virus

\section{Giriş}

1959 y1linda, 5-Substituted 2'-Deoxyuridine (IDU)'nin tanımlanmasıyla birlikte, viral enfeksiyonların tedavi edilebileceği fikri ortaya atılmış oldu. Bu bilgiler 1şı ğında yapılan denemeler sonucunda in vitro koşullarda, antiviral aktivite keşfedildi.1962 yılına gelindiğinde ise ilk kez etkili bir herpes simplex virus (HSV) keratitis tedavisi gerçekleştirdi. Böylece IDU, herpetik göz enfeksiyonlarında topikal sağaltımda kullanılan ilk antiviral ajan haline geldi. Kaufmann ve Heidelberger'in 1964 y1lında, 5-trifluoro- 2'Deoxythymidine'nin antiviral etkinliğini ortaya koymasıyla beraber, HSV keratitisin topikal tedavisinde yüksek başarı sağlandı. Yine aynı tarihte, adenine arabinoside'nin HSV üzerindeki antiviral etkisi kanıtlanmış ve ilk kez herpesvirus enfeksiyonlarının sistemik sağaltımında kullanılmıştır. 1964 yılı içerisinde, influenza A virus inhibitörü olan amantadinenin, antiviral etkisinin invitro ve invivo ortamlarda kanitlanmasina karşın etkenin ajana karşı hızla geliştirdiği direnç nedeniyle pratikte istenilen sonuca ulaşılamamıştır.
1977 yılında, herpesviruslara karşı selektif ilk antiviral ajan olan 9-(2-hydro-xyethoxymethyl) guanine (asikloguanosin) sentezlendi, birkaç ay sonra asikloguanosine oranla daha geniş bir etki spektrumuna sahip olan (S)-9-(2,3-dihydroxypropyl) adenine (DHPA) geliştirildi. 1983 yılında, Human immunodeficiency virus (HIV)'un sebep olduğu, “Acquired Immunodeficiency Syndrome" (AIDS)'in tanımlanmasından günümüze kadar, bu hastalığın sağalt1mında kullanılmak üzere pek çok antiretrovirus ajan geliştirilmiştir (reltegravir, dolutegravir, ritonavir, maraviroc vb.) ve geliştirilmeye devam etmektedir. Bunun yanı sıra, Hepatitis B virus (HBV) ve Hepatitis $\mathrm{C}$ virus (HCV) gibi büyük salgınlara yol açan enfeksiyonların tedavilerinde kullanılmak üzere antiviral ajan geliştirme çalışmaları sürdürülmektedir (Asunaprevir, bocaprevir, paritaprevir, elbasvir vb.) $[18,19,32]$.

Günümüze kadar geçen sürede geliştirilen antiviral ilaçlar etki mekanizmalarına göre 12 ana başlık altında toplanabilir. 


\section{5-Substituted 2'-Deoxyuridine Analogları}

$\mathrm{Bu}$ grup içerisinde üç farklı (İdoxuridine, Trifluridine, Brivudine) antiviral ajan bilunur. 1959 yılında idoxuridine'nin tanımlanması ile birlikte antiviral ajanların tarihi başlamış oldu. İlaç ilk olarak kanser tedavisinde kullanılmak üzere geliştirilmiştir. Daha sonra yapılan çalışmalarda herpetik göz enfeksiyonlarının topikal sağaltımında da etkili olduğu görülmüştür. İdoxuridine'nin antiviral etkisinin anlaşılmasını takiben 1964 yılında Heidelberg ve Kaufmann tarafindan Trifluridine üretilmiştir. $\mathrm{Bu}$ iki ajan günümüzde de Herpes Simplex Virus-1 (HSV-1)' in neden olduğu epitelyal keratitis olgularının sağaltımında merhem ve damla formunda kullanılmaktadır [10,47]. Brivudine ise Birmingham Üniversitesi Kimya Bölümü tarafindan 1976 yılında üretilmiş olup HSV-1 ve Varicella-Zoster Virus (VZV)'e karşı seçici ve etkili bir ajan olarak kabul edilmektedir [20].

$\mathrm{Bu}$ ajanların antiviral mekanizmaları benzerdir. Viral timidin kinaz ve konakçı hücrelerin sahip olduğu diğer enzimler ile fosforile olurlar. Böylece, hem viral hem de hücresel DNA polimeraz enzimini inhibe ederler. Ancak virus üzerinde göstermiş olduğu etkiyi konakçı hücreleri üzerinde de göstereceğinden ötürü parenteral uygulamaya uygun değildir. Brivudine'nin diğer ajanlardan daha selektif ve efektif olmasının sebebi HSV-1 ve VZV viral timidin kinaz enzimine spesifite göstermesidir $[19,44,73]$.

Herpetik keratitisin tedavisinde bruvidine, idoxuridine, trifluridine ve acyclovir etken madde içeren oftalmik preparatların sağaltımda neredeyse aynı derecede etkiye sahip olduğu görülmüştür. Uygulama sonrası 2 hafta içerisinde \% 90'a yakın bir iyileşme söz konusudur. Fakat, HSV-1 ve VZV enfeksiyonlarının sistemik sağaltımında toksik etkisinden ötürü idoxuridine ve trifluridine yerine brivudinenin tercih edilmesi prognoz açısından daha güvenlidir $[6,76]$.

\section{Nükleosit Analogları}

Bu grup, içerisinde üç farklı (Telbivudine, Lamivudine, Vidarabine) antiviral ajan barındırmaktadır. Vidarabine'nin etki mekanizması, viral DNA polimerazın inhibisyonu üzerine kuruludur [70]. Bir diğer nükleosit analoğu olan Telbuvidine bir timidin analoğudur ve viral reverse transkriptazın yarışmalı inhbitörüdür. Viral reverse transkriptazın ve viral DNA polimerazın inhibisyonunu sağlayarak antiviral etki gösterir. Entecavir ise bir diğer nükleosit olan guanosinin analoğudur. HBV'nin viral DNA polimeraz ve viral transkriptaz enzimleri üzerinde inhibisyon etkisi gösterir [64].

1976 yılında nükleosit analogları içerisinde onaylanan ilk ajan olan vidarabine HSV-1, HSV-2, VZV ve hatta bazı AIDS hastalarının sağaltımında kullanılmıştır fakat toksik etkisinden ötürü yerini daha efektif ve güvenilir ajanlara bırakmıştır [29]. \%3'lük merhem olarak kullanılırsa keratokonjuktivitis sicca sağaltımında etkili olmaktadır ve kedilerde idoxuridine göre daha kolay tolare edilebilmektedir [45]. Telbivudin 2006 yllinda ABD'de, spesifik olarak Hepatitis B virus (HBV) enfeksiyonu tedavisi için geliştirilmiştir [64]. Oral yolla kullanıldığında biyoyararlanımı en yüksek seviyeye ulaşmaktadır. Ajan, klinik öncesi yapılan testlerde denekler üzerinde herhangi bir mutojenik ve karsinojenik etki bırakmamıştır. Gebelerde kullanılması durumunda, embriyoda veya fötüste toksik bir durum yaratmamaktadir. Entecavir ve Telbivudinin serumdaki HBV DNA seviyesini lamivudine göre çok daha aşağ1 seviyelere düşürdüğü gözlemlenmiştir $[11,23,40]$. Lamivudine, hepadnavirus DNA'sında zincir sentezini inhibe etmek üzere geliştirilmiş bir oral sitozin nükleosit analoğudur [8]. Ajan, HBV viral replikasyonunu suprese ederek serum alanin aminotransferaz seviyesinin normal değerlere ulaşmasını sağlar. Bununla birlikte, karaciğer yangısını ve hepatosit parçalanmalarının da önüne geçer. Viral DNA replikasyonunu etkili bir biçimde inhibe eden ve hastalığın yayılmasını engelleyen lamivudin, HBV tedavisinde en yaygın kullanılan nükleosit analoğudur [7, 12].

\section{Asiklik Nükleosit Fosfonat Analogları}

Sidofovir ve Adefovir önemli asiklik nükleosit fosfonat analogları içerisinde sayılabilir. Bu gruptaki ajanların etki mekanizması, viral DNA polimerazın fosfonoasetik asit ile hibridizasyonu ile inhibisyonu esasına dayanır [19].

Bir sitozin analoğu olan sidofovir, sentezlendiği ilk y1llarda AIDS ve cytomegalovirus (CMV) etkenlerinin neden olduğu rinitis tedavileri için geliştirilmiş olsa da günümüzde herpesvirus, adenovirus, polymovirus ve papillomavirus enfeksiyonlarının 
tedavilerinde kullanılır [57]. Viral DNA polimeraz enzimine duyduğu yüksek affinite sebebiyle oldukça güvenlidir. HSV-1 enfeksiyonlarında intravenöz veya intravitreal olarak kullanıldığ [73]. Veteriner hekimliğinde, kedilerde deneysel olarak günde $2 \mathrm{kez}$ uygulanan ve metilselüloz içeren sidofovirin, Feline Herpesvirus -1 (FeHV-1) virusunun saçılımını engellediği ve klinik semptomları kısmen de olsa hafiflettiği ortaya çıkmıştır. İn vitro ve in vivo etkileriyle bu anti viral ajanın FeHV-1 karşısında etkin olduğu kesinleşmiştir. Ancak, hayvanlar nazolakrimal sikatrizasyon yönünden gözetim altında tutulmalıdır [27].

2002 y1lında geliştirilmiş olan adefovir dipivoxil adenozin monofosfatın nükleotit analoğudur. Ortaya ilk çıtı̆ğ dönemde HIV tedavisinde kullanılsa da renal toksisitesi nedeniyle vazgeçilmiştir. HBV antijen negatif ve pozitif kronik hastalar için kullanılır. Adefovir dipivoxil alındıktan sonra esteraz ile adefovir formuna bürünür bu olayı takiben hücre içi fosforilasyon ile beraber adefovir difosfat meydana gelir. Adefovir difosfat deoxyadenozin trifosfatın analoğudur ve DNA zincirinin uzamasını engeller [69]. Lamivudin direnci kaydedilmiş olan ve kan serumlarında HBV antijeni bulunan veya bulunmayan, kronik HBV enfeksiyonlu hastalarda yapılan ilk denemelerde adefovir dipivoxilin, serum HBV DNA varlığını büyük ölçüde azalttığı ve serum alanin aminotransferazı (ALT) normal seviyelere düşürdüğü gözlemlenmiştir [7].

\section{Asiklik Guanozin Analogları}

Asiklik guanozin analogları içerisinde 6 farklı (asiklovir, valasiklovir, gansiklovir, valgansiklovir, famsiklovir, pensiklovir) antiviral ajan sayılabilir. $\mathrm{Bu}$ ajanların etki mekanizmaları viral ve hücresel timidin kinaz enzimleri ile fosforilasyona dayanır. İlk fosforilasyonlarını viral timidin kinaz enzimi ile gerçekleştiren ajanlar devamında hücresel timidin kinaz ile fosforilasyon işlemlerini tamamlarlar. Fosforilasyon sonucu trifosfat forma dönüşen ajanlar viral DNA polimerazın uzamasını engeller $[13,19,57]$.

Asiklovir, ilk olarak 1974 yılında İngiltere'de geliştirilen bir antiviral ilaçtır. HSV-1, HSV-2 ve varicella-zoster virus (VZV) enfeksiyonlarının tedavilerinde kullanılmaktadır [57]. Veteriner hekimliğinde kedilerin önemli üst solunum yolu enfeksiyon- larından biri olan FeHV-1 enfeksiyonunun tedavisinde denenmiştir. Ancak, FeHV-1'in timidin kinaz fosforilasyon etkinliğinin, HSV-1'e göre oldukça düşük olması sebebiyle asiklovirin FeHV-1 üzerindeki etkisi zayıftır. Kedilere, \%0.5'lik göz damlası şeklinde günde $5 \mathrm{kez}$ uygulandığında 10 güne kadar klinik semptomlarda azalmalara rastlanmıştır $[30,73]$. Valasiklovir, asiklovirin biyoyararlığını artırmak için geliştirilen bir ön ilaçtır. Gastrointestinal kanalda absorbsiyonunun hizlı olması enfeksiyonlara karşı asiklovire göre daha etkili olmasını sağlamıştır. Emilimden sonra hepatik hidrolaz enzimi ile asiklovire dönüştürülür [44,57].

$\mathrm{Bu}$ grup içerisinde yer alan bir diğer guanin analoğu ise gansiklovirdir, etki mekanizması asiklovire çok yakın olan bu ajan immun sistemi baskılanmış CMV enfeksiyonu bulunan hastalarda kullanılmak üzere geliştirilmiştir. Bunun yanı sıra, HSV-1' in neden olduğu konjuktivitis olgularında da etkili olduğu gözlemlenmiştir [5]. Valgansiklovir, oral yolla uygulandığında düşük biyoyararlılık gösteren gansiklovirin biyoyararlılığını artırmak için geliștirilmiș bir ön ilaç formudur ve AIDS hastalığ bulunan insanlarda CMV renitisin tedavisinde kullanılmaktadır $[15,46]$. Bir nükleosit deoksiguanozin analoğu olan pensiklovir, insanlarda HSV-1, HSV-2 ve VZV gibi enfeksiyonların tedavisi için geliştirilmiștir. İn vivo ve in vitro şartlar göz önünde tutulduğunda FeHV-1'e karşı da oldukça etkilidir [30,31].

Famsiklovir, pensiklovirden yüksek biyoyararlanım elde edebilmek için geliştirilmiş bir ön ilaçtır. Oral kullanıldığında plazmada ya da ince bağırsakta di-deasetilizasyona uğrayarak 6-deoksipensiklovire (BRL 42359) dönüşen ajan, hepatik aldehit oksidaz enzimi ile oksitlenip pensiklovire dönüşür [28]. Pensiklovir, viral enfekte hücreye girer ve fosforilasyona uğrayarak aktif trifosfat formuna bürünür. İlk basamakta viral timidin kinaz ile katalize olurken takip eden basamaklarda katalize olmak için konakçı enzimlerini kullanır [34]. Yapılan in vitro çalışmalarda famsiklovirin ve BRL 42359'un tek başlarına FeHV-1 üzerinde herhangi bir etkilerinin olmadığ 1 gözlemlenmiștir. Bu bilgi 1şığında etkin bir sağaltım için antiviral ajanın oksidasyonunun tamamalanıp pensiklovir formuna dönüşmesi gereklidir. Ancak kedilerde, BRL 42359'un oksidasyonu için gerekli olan hepatik aldehit oksidaz aktivitesi $\% 2$ civarında seyretmektedir ve bu yüzde diğer pek 
çok canlıya göre oldukça düşüktür. Hepatik aldehat oksidaz seviyesindeki doygunluktan kaynaklandığ düşünülen aktivasyondaki bu düşüklük, kedilerde famsiklovirin farmakokinetiğinin oldukça farklı olmasına yol açmaktadır [68].

\section{Pirofosfat Analoğu}

Foscarnet viral antiviral ajanlar arasında en küçük boyutlu olandır ve mutlaka damar içi yolla uygulanmalıdır. İlk olarak insanlarda CMV enfeksiyonunun tedavisi için geliştirilse de sonraları, asiklovire direnç gösteren HSV ve VZV enfeksiyonları üzerinde de uygulanmıştır. Viral DNA polimeraz üzerinde bulunan pirofosfat bağlama bölgesindeki anyon prifosfatı taklit ederek etki eder. Veteriner hekimliğinde de kullanılan ajan, kedilerde oral yolla uygulamada, biyoyararlılığı yaklaşı \% 8 'lerde seyrettiği için yaygın olarak kullanılmamaktadır $[1,73]$.

\section{İntegraz İnhibitörleri}

Retroviral ajanlar, konakçı hücrelerde çoğalıp saçılabilmek için proteaz, integraz ve reverz transkriptaz enzimlerine ihtiyaç duyarlar. Etkenin konakçı hücreye penetrasyonunu reverz transkriptaz ile viral DNA replikasyonu izler. Replikasyon sonucu viral integrazlar proviral DNA'nın 3' ucunu çeşitli prosesler ile konakçı hücre genomuna entegre eder. İntegraz inhibitörlerinin etki mekanizması, enzimin katalitik bölgesinde bulunan $\mathrm{Mg}^{+2}$ ye bağlanarak, virusun entegreasyon aşamasını inhibe etmek üzerine kuruludur [51,53]. İlk HIV inhibitörleri 2007 yılında geliştirilmiştir. Reltegravir, dolutegravir ve elvitegravir adı verilen bu ajanlar genellikle, "highly active antiretroviral therapy" (HAART) için kullanılmaktadir [22].

Reltegravir integraz inhibitörleri arasında ilk onaylanan ilaçtır. HIV-1 RNA seviyesi yüksek, CD4 hücre sayısı düşük olan hastalar üzerinde kullanılan ajanın oldukça etkili olduğu görülmüştür. Bunun yanı sıra reltegravir, nükleosit analoglariyla ve rifonovir ile kombine edilebilir [19,22]. Elvitegravir onaylanmış ikinci integraz inhibitörüdür, tek başına etki gösterebileceği gibi, emtricitabine, tenofovir alafenamide, tenofovir disoproxil fumarate, cobisitatlar ile de kombine edilerek kullanılabilir [77]. Elvitegreavir, reltegravir ile benzer direnç mutasyonları paylaştıkları için, reltegravir dirençli HIV1 enfeksiyonlarında kullanılmamalıdır [58]. Dolu- tegravir, 2013 yılında reltegravir ve elvitegravire direnç gösteren retroviral ajanların sebep olduğu enfeksiyonların sağaltımında kullanılmak üzere geliştirilmiştir. Tek başına etki gösterebileceği gibi, abacavir ve lamuvidine ile kombine edilerek de kullanılabilir [53].

\section{Giriş İnhibitörler}

Giriş inhibitörlerin etki mekanizması, virusların konakçı hücre membranına adsorbsiyonunu ve hücre içine penetrasyonunu engellemek üzere kurulmuştur. $\mathrm{Bu}$ grup içerisinde, retroviridial enfeksiyonlara karş1 geliştirilen enfuvirtide, maraviroc; herpetik enfeksiyonlara karşı geliştirilen docosanol gibi ajanları barındırır [19].

HIV etkeninin zar proteinlerinden biri olan gp120 konakçı hücrenin CD4 lökosit reseptörüne bağlanır, bu bağlanma aşamasında gp120 üzerindeki özel yapılar konakçı hücre yüzeyinde bulunan CCR5 veya CXCR4 reseptörlerine adsorbe olur [59]. Adsorbsiyonu takiben gp41'de konformatif değişimler meydana gelir. Bu değişimler sonucu, $\mathrm{N}$-Heptad repeat ve C-Heptad repeat bölümleri bir araya gelerek alt1lı sarmal demeti meydana getirir ve konakçı hücre membranı ile virus membranı arasinda bir füzyon oluştur [26]. Oluşan bu füzyon ile etken hücreye penetre olur [9].

Enfuvirtide, 2003 y1lında onaylanan ilk giriş inhibitörüdür. Ajan, HIV'in gp41 yüzey proteinini inhibe ederek etkenin konakçı hücreye penetrasyonunu engeller [24]. Bunun yanısıra ajan düşük biyoyararlanıma sahiptir ve gastrointestinal sistem proteazlarına karşı duyarlıdır [35]. Bu nedenle invivo ortamda yarılanma ömrü yaklaşık 4 saattir ve günlük paranteral yolla uygulanması gerekir [54].

Maraviroc, 1996 yılında kemokin reseptörü olarak geliştirilmiş ilk antiviral ilaçtır. Ajan, konakçı hücre yüzeyinde bulunan CCR5 kemokin reseptörüyle HIV gp120 yüzey proteinin arasında bağlantı kurulmasını engelleyerek antiviral etki meydana getirir [55]. Hücre kültürleri üzerinde yapılan bazı deneylerde, proteaz inhibitörleri, nükleaz reverz transkriptaz inhibitörleri ve non-nükleaz reverse transkriptaz inhibitörleri maraviroc ile kombine edilip uygulandığında aralarında antagonizm gelişmediği gözlemlenmiştir. Bunun yanısıra, maraviroc'un bir diğer giriş inhibitörü olan enfuvirtide 
ile kombinasyonu HIV-1' in sağaltımında sinerjist bir etki göstermiştir [72].

Yirmi iki karbon uzunluğunda, doymuş bir primer alkol olan docosanol, HSV, VZV, RSV gibi zar11 viruslar üzerinde etkilidir [41,62]. Etki mekanizmas1, etkenin konakçı hücreye adsorbiyonunu engelleme ve viral replikasyonun inhibisyonu üzerine kuruludur [30,41]. Docosanol, trifluride ve idoxuridine gibi non selektif bir yapıya sahip olduğu için parenteral uygulamalarda toksik bir etki meydana getirmektedir. Bu nedenle, sadece topikal sağaltımlarda kullanılır [52].

\section{Proteaz İnhibitörleri}

Proteaz inhibitörleri, HIV ve hepatit $\mathrm{C}$ virus (HCV) enfeksiyonlarının tedavilerinde uygulanmak üzere geliştirilseler de, herpesvirus, picornavirus, flavivirus, filovirus kaynaklı hastalıkların sağaltımında da kullanılmaktadır [3].

Proteaz, HIV replikasyonunun son aşamasında önemli bir yer tutar. Enzim, viral gag ve gagpol precursor proteinlerinin işlenmesinde rol oynayarak olgun enfektif virus partiküllerinin oluşmasını sağlar [74]. Bu ajanların etki mekanizması, proteaz enziminin aktif bölümlerine bağlanarak viral poliproteinlerin oluşumunu ve yayılmasını engellemek üzerine kurulmuştur [3].

1995 yılında piyasaya sürülen saquinavir üretilen ilk proteaz inhibitörüdür. AIDS hastalarının sağaltımında kullanılmak üzere geliştirilmiştir [43]. Saquinavirin üretilmesini takiben ritonavir, indinavir ve nelfinavir piyasaya sürülmüştür. Birinci nesil HIV proteaz inhibitörleri olan bu ajanlar, düşük biyoyararlanımlarının yanısıra hepatotoksik, nefrotoksik, gastrointestinal sistem bozuklukları gibi yan etkiler meydana getirdikleri için günümüzde yaygın olarak kullanılmamaktadır [3,75]. İkinci kuşak HIV proteaz inhibitörleri lopinavir, amprenavir, atazanavir, tipranavir, darunavir antiviral ilaçlarını içerir. $\mathrm{Bu}$ ajanlar, birinci kuşak proteaz inhibitörlerinin neden olduğu yan etkilerin azaltılması ve biyoyararlanımın artırılması için geliştirilmiştir [3].

HIV'in proteaz enziminde meydana gelen primer ve sekonder mutasyon direnci, proteaz inhibitörü uygulanan hastalarda direnç oluşumuna sebep olabilmektedir [75]. Direnç oluşumuna karşın, proteaz inhibitörleri, Amerika Birleșik Devletleri'nde ve pek çok Avrupa ülkesinde Lopinavir/Ritonavir, Darunavir/Ritonavir, Saqunavir/Ritonavir gibi ajanlar kombinasyon olarak kullanılmaktadır [12].

HIV'de olduğu gibi HCV'nin yaşam siklusunda da proteaz önemli bir yer kaplar. NS4A ve NS3 proteaz enzimi, viral poliproteinlerin olgunlaşmasinda önemli rol oynar [21]. Proteaz inhibisyonu amaciyla geliștirilmiș olan her ajan proteaz enziminin aktif bölümüne bağlanarak antiviral etki gösterir [66]. HCV NS3/4A proteaz inhibitörleri arasında, vaniprevir, boceprevir, asunaprevir, grazoprevir, paritaprevir, simeprevir ve telaprevir örnek olarak gösterilebilir [19]. Japonyada, HCV-1 ile enfekte olan hastalar üzerinde, asunaprevir+declatasvir ve vaniprevir+PegIFN $\alpha-2 b+$ ribavirin gibi ilaç kombinasyonlarının denendiği bildirilmiştir [31]. 2015 yılında geliştirilen, grazoprevir+elbasvir kombinasyonu ise HCV-1 ve 4 enfeksiyonlarının her ikisinin tedavisinde de uygulanmıştır [49].

\section{Nükleozit Reverz Transkiptaz İnhibitörleri (NRTi)}

Reverz transkriptaz, retroviral etkenlerin viral ssRNA genomundan dsDNA sentezlenme aşamasında rol oynayan en önemli enzimlerinden biridir [17]. NRTI'ler, konakçı hücrede var olan kinaz ve fosfotransferaz enzimleri ile fosforile olarak deoxynükleosit trifosfat (dNTP) analoğuna dönüşür. Bu yapı, endojen dNTP'ler ile yarışmalı olaral viral reverz transkriptaz'a bağlanır ve zincir yapısını bozarak viral replikasyonu inhibe eder [14]. 1987 yılinda onaylanan ilk NRTİ zidovudinedir. Retroviral enfeksiyonların tedavisinde viral reverz transkriptaz inhibisyonunun olumlu sonuç vermesi üzerine etki mekanizmaları zidovudine'ye benzer yeni ilaçlar geliştirilmiştir. Bunlar zalcitabine, emtricetabine, lamivudine, stavudine, abacavir, didanosine'dir [19].

Nükleozit reverz transkriptaz inhibitörlerine karş1 ilaç direnci çok çabuk şekillendiği için bu ajanlar, HIV tedavilerinde virusun yaşam siklusunun başka bir aşamasını inhibe ederek antiviral etki gösteren ajanlarla kombine edilerek kullanılır [12]. Lamivudine+dolutegravir, emtricetabine $+\mathrm{T}$ $\mathrm{DF}$, emtricetabine+TDF+elvtitegravir+cobicistat bu kombinasyonlardan bazılarıdır $[19,61]$. 


\section{Non-Nükleozit Reverz Transkriptaz İnhibitörleri (NNRTi)}

NNRTİ viral reverz transkriptazın, allosterik bölgesi olan katalitik bölgeyi hedef alarak antiviral etki gösteren nonkompetif bir inhibitör grubudur. İnhibitörlerin hedef alınan bölgeye bağlanmasını takiben etkenin katalitik etkinliği azalır, bunun sonucu viral replikasyon inhibe edilmiş olur [2,16].

1980' li yılların sonlarına doğru rilpivirinen, delavirdine, evirapine, efavirenz, etravirine gibi ajanlar geliştirilmiştir [19].

\section{M2 (Matrix 2) Protein İnhibitörleri}

İnfluenza A virus'un integral membran proteini olan M2 proton kanalı işlevi, etkenin konakçı hücreye girişi sırasında viral membranda; etken ile enfekte hücrede viral maturasyon aşamasında ise trans-golgi membranda $\mathrm{pH}$ düzeyini dengelemektir $[39,56]$.

İnfluenza A virus enfeksiyonlarının tedavisinde kullanılmak üzere geliştirilen amantadine ve rimantadine, $\mathrm{H}^{+}$iyonlarının $\mathrm{M} 2$ protein kanallarıyla viral yapıya aktarılmas1 engelleyerek iyon konsantrasyonunda bir değişim meydana getirir. Bu değişim, influenza virus nükleik asidinin kapsitten ayrılmasını inhibe eder ve antiviral etki meydana gelir [37,42].

Amantidine ve ramantadine, özellikle enfeksiyonun ilk 48 saatinde kullanıldığında semptomlarda kayda değer bir azalma meydana getirmektedir. Fakat, ajana karşı gelişmiş olan dirençten ötürü kullanım sahası daralmıştır. Yapılan denemelerde, amantadine ve rimantadine'nin benzer etkilere sahip olduğu anlaşılmıştır, fakat nörolojik yan etkiler rimantadine' de amantidine'ye oranla daha düşüktür [60].

\section{Nöroaminidaz inhibitöleri (NAI)}

İnfluenza virusların hemaglutinin, nöroaminidaz ve M2 olmak üzere 3 adet yüzey proteini bulunmaktadır. Hemaglutinin, virusun hücre reseptörleri üzerindeki terminal sialik asitlere bağlanmasını sağlarken, M2 proteini viral replikasyon aşamasında $\mathrm{pH}$ dengesini sağlamakla görevlidir [48]. Nöroaminidaz ise, replikasyon sonrası oluşan yeni virus partiküllerinin hücre yüzeyinden salınımından sorumludur [4]. Nöroaminidaz inhibitörleri, bu protein üzerine etkiyerek oluşan yeni virus partiküllerinin saçılımını engellemek suretiyle antiviral etki gösterir [50].
1999 y1lında geliştirilen ve ilk NAI olan zanamivir, nöroaminidazın epitoplarına sialik asitten daha fazla affinite gösterir. İnhalasyon yolu ile kullanılan ajanın \%15'i alt solunum yollarında kalır [36]. Zanamivir, influenza B ve H1N1 suşu üzerinde oseltamivire oranla daha yüksek aktivite gösterse de H3N2 suşunda oseltamivirden düşük bir etki meydana getirir [63]. Oseltamivir, zanamivirin yapısı örnek olarak geliştirilmiş ve aktif formuna karaciğerde dönüşmek üzere geliştirilmiş bir ön ilaçtır. İlaç hap veya şase şeklinde oral uygulandığında yüksek bir biyoyararlanım gösterir [38,50].

\section{Antiviral Etki Gösteren Diğer Ajanlar}

\section{Interferonlar}

Viral enfeksiyonlara karşı hücrelerin temel savunma mekanizması olan interferonlar immunolojik ve antiviral fonksiyonları diğerlerinden farklı olan sitokinler olarak tanımlanabilir. İlk olarak 1957 y1lında keşfedilmiştir ve hala üzerinde çalışmalar yapılmaktadır. Alfa, beta, gamma $(\alpha, \beta, \gamma)$ olmak üzere 3 tipi ve bu tiplerin pek çok alt tipi bulunmaktadır [73]. Viral replikasyonun baskılanmasında büyük bir rol oynayan interferon tip I, ağırlıklı olarak hematopoetik hücrelerden salgılanır ve vücudu antiviral aktivite için uyarır. Yapılan son çalışmalar, patojen ile ilişkili moleküler patternlerin (PAMPs) interferon üretimini tetiklediğini ortaya koymuştur. Viral bir enfeksiyon sirasında virusun RNA tanskripsiyon aşaması PAMP reseptörleri tarafinda algılanmaktadır. Enfeksiyonun ilk saatlerinde, hücrelerde interferon tip 1 ve tip 3'ünde aralarında olduğu bazı gen gruplarında aktivasyon şekillenmektedir. Aktive olan bu interferonlar, interferon stimule edici genleri (ISG) aktive eder. Şekillenen bu gen aktivasyonu, viral replikasyonun farklı adımlarını inhibe eden antiviral etkenlerin oluşumuna katılır [19,67].

$\mathrm{HBV}$ ve HCV enfeksiyonlarının tedavisinde kullanılan 3 farklı interferon preparatı geliştirilmiştir. Bunlar, Interferon Alfacon-1, Pegylated İnterferon $\alpha-2 \mathrm{a}$ (PegIFN $\alpha-2 \mathrm{a})$ ve PegIFN $\alpha$-2b dir. Ciddi yan etkilerinden ötürü Interferon Alfacon-1, 2013 yılında kullanımdan kaldırılmıştır. PegIFN $\alpha$ kökenli ajanlar, HBV sağaltımında kullanılırken, HCV sağaltımında yaygın olarak kullanılmamaktadır. Bunun sebebi, HCV sağaltımında, interferon içermeyen ajanların, içerenlere oranla daha etkili 
olmasıdır [33,73]. İnterferon tedavisi, insan sağlığı yanı sıra veteriner hekimliğinde de kullanılmaktadir. İn vitro ortamda $1 \times 10^{5}$ den $5 \times 10^{5} \mathrm{IU} / \mathrm{ml}$ 'ye kadar uygulanan ve kedilerde son zamanlarda tespit edilen feline IFN $\omega$ 'nin sitotoksitite göstermeden FeHV-1 titresini düşürdüğü gözlemlenmiştir. Ayr1ca yüksek konsantrasyonlarda IFN $\omega$, IFN $\alpha$ ya göre çok daha etkili bulunmuştur [65,71]. Bir diğer in vitro çalışmada, $10-62,5 \mu \mathrm{g} / \mathrm{mL}$ asiklovir $10-100$ $\mathrm{IU} / \mathrm{ml}$ rekombinant insan IFN $\alpha$ ile kombine edilmiş ve bu kombinasyon herhangi bir sitotoksik etki göstermediği gibi FeHV-1'in maximal inhibisyonu için gerekli olan asiklovirin dozunu yaklaşık 8 kat düşürmüștür. $\mathrm{Bu}$ verilere göre interferonların nükleosid analogları ile birlikte kullanılmaları tavsiye edilmektedir [73].

Lizin; Çoğunlukla herpetik enfeksiyonların tedavisinde kullanılan aminoasit yapıda bir ajandır. Antiviral etkisi, herpevirusların replikasyonunda esansiyel olan argininin antagonisti olmasıdır, bu antogonizm viral protein sentezini inhibe eder [73].

Lambda- Carrageanan; Sülfat polisakkarit içeren bir deniz yosunu ekstraktıdır, viral zar glikoproteinlerine bağlanarak etkenin konakçı hücreye adsorbsiyonunu engeller [25].

\section{Sonuç}

İlaç sanayisinde antiviral ilaçların geliştirilmesi diğer antimikrobiyal ilaçlara göre daha geride kalmıștır. Ancak günümüzde biyoteknolojinin ve moleküler genetiğin hızlı gelişmesinden dolayı spesifik olarak viral enfeksiyonların tedavisi amaciyla antiviral ilaçların geliştirilmesi hususunda önemli mesafeler alınmıştır. Bu ilaçların yan etkilerinin azaltılarak rutinde kullanıma sokulmaları viral kaynaklı enfeksiyonların profilaksi ve tedavisinde oldukça faydalı olacaktır.

\section{Kaynaklar}

1. Adalsteinsson JA, Pan M, Kaushik S, Ungar J, (2018). Foscarnet-induced genital lesions: An overview with a case report. Dermatol Reports.10, 12-13.

2. Adams J, Patel N, Mankaryous N, Tadros M, Miller CD, (2010). Nonnucleoside Reverse Transcriptase Inhibitor Resistance and the Role of the Second-Generation Agents. Ann Pharmacother. 44, 157-165.

3. Agbowuro AA, Huston WM, Gamble AB, Tyndall JDA, (2018). Proteases and protease inhibitors in infectious diseases. Med Res Rev. 38, 1295-1331.
4. Air GM, (2012), İfluenza neuraminidase. İnfluenza Other Respir Virus. 6,245-256.

5. Al-Badr AA, Ajarim TDS, (2018). Ganciclovir. Brittin HG. Eds. Profiles of Drug Substances, Excipients and Related Methodology vol 43. Academic Press Inc, USA, 1-208.

6. Andrei G, Sienaert R, McGuigan C, De Clercq E, Balzarini J, Snoeck R, (2005). Susceptibilities of several clinical varicella-zoster virus (VZV) isolates and drug-resistant $V Z V$ strains to bicyclic furano pyrimidinenucleosides, Antimicrob Agents Chemother. 49, 1081-1086.

7. Angus P, Vaughan R, Xiong S, Yang H, Delaney W, Gibbs C, Brosgart C, Colledge D, Edwards R, Ayres A, Bartholomeusz A, Locarnini S, (2003). Resistance to Adefovir Dipivoxil Therapy Associated With the Selection of a Novel Mutation in the HBV Polymerase. Gastroenterology. 125, 292-297.

8. Arslan U, Ural O, Findık D, (2008). Lamivudin tedavisi alan kronik hepatit B olgularında inno-lipa HBV DR yöntemi ile saptanan YMDD motif değişiklikleri, Mikrobiyol Bul. 42, 445-450.

9. Berkhout B, Eggink D, Sanders RW, (2012). Is there a future for antiviral fusion inhibitors.

10. Białek-Pietras M, Olejniczak AB, Paradowska E, Studzinska M, Jabłonska A, Lesnikowski ZJ, (2018). Synthesis, susceptibility to enzymatic phosphorylation, cytotoxicity and in vitro antiviral activity of lipophilic pyrimidine nucleosidel carborane conjugates. J Organomet Chem. 865, 166-172.

11. Chang T, Gish R, De Man R, (2006). A comparison of entecavir and lamivudine for HBeAg-positive chronic hepatitis B. N. Engl. J. Med. 354, 1001-1010.

12. Charpentier C, Camacho R, Ruelle J, Eberle J, Gurtler L, Pironti A, Sturmer M, Brun-Vezinet F, Kaiser R, Descamps D, Obermeier M, (2015). HIV-2EU-supporting standardized HIV-2 drug-resistance interpretation in Europe: an update. Clin Infect Dis. 61, 1346-1347.

13. Chou TY, Hong BY, (2014). Ganciclovir ophthalmic gel $\% 0.15$ for the treatment of acute herpetic keratitis: background, effectiveness, tolerability, safety, and future applications. Ther Clin Risk Manag. 10, 665-681.

14. Cihlar T, Ray AS, (2010). Nucleoside and nucleotide HIV reverse transcriptase inhibitors: 25 years after zidovudine. Antiviral Res. 85,39-58. Curr OpinVirol. 2, 50-59.

15. Curran M, Noble S, (2001). Valganciclovir. Drugs. 61, 1145-1150.

16. D'Cruz OJ, Uckun FM, (2006). Dawn of non-nucleoside inhibitor-based anti-HIV microbicides. J Antimicrob Chemother. 57,411-423.

17. Das K, Arnold E, (2013). HIV-1 reverse transcriptase and antiviral drug resistance. Part 1. Curr Opin Virol. 3,111118.

18. De Clercq E, (2009). Looking back in 2009 at the dawning of antiviral therapy now 50 years ago: An historical perspective. Adv Virus Res. 73, 1-53.

19. De Clercq E, Li G, (2016). Approved antiviral drugs over the last 50 years. Clin Microbiol Rev. 29, 695-747.

20. De Clercq, (2004). Discovery and development of BVDU (brivudin) as a therapeutic for the treatment of herpes zoster. Biochem Pharmacol. 68, 2301-2315. 
21. De Leuw P, C Stephen, (2018). Protease inhibitor therapy for hepatitis $\mathrm{C}$ virus-infection. Expert Opin Pharmacother. 19, 577-587.

22. De Miguel R, Montejano R, Stella-Ascaris N, Arribas JR, (2017). A safety evaluation of raltegravir for the treatment of HIV. Expert Opin Drug Saf. 17, 217-223.

23. Dienstag JL, Goldin RD, Heathcote EJ, Hann HWL, Woessner M, Stephenson SL, Gardner S, Gray DF, Schiff ER, (2003). Histological Outcome During Long-term Lamivudine Therapy. Gastroenterology. 124, 105-17.

24. Dingens AS, Arenz D, Overbaugh J, Bloom JD, (2018). Massively parallel profiling of $H I V-1$ resistance to the fusion inhibitor enfuvirtide. BioRxiv 472746, Erişim tarihi: 06.12.2018.

25. Diogo JV, Novo SG, Gonzalez MJ, Ciancia M, Bratanich AC, (2015). Antiviral activity of lambda-carrageenan prepared from red seaweed (Gigartina skottsbergii) against BoHV-1 and SuHV-1, Res Vet Sci. 98,142-144.

26. Este JA, Telenti A, (2007). HIV entry inhibitors. Lancet, $370,81-88$.

27. Fontenelle JP, Powell CC, Veir KJ, Radecki SV, Lappin RM, (2008). Effect of topical ophthalmic application of cidofovir on experimentally induced primary ocular feline herpesvirus-1 infection in cats. Am J Vet Res. 69, 289-293.

28. Groth DA, Contreras MT, Kado-Fong HK, Nguyen KQ, Thomasy SM, Maggs DJ, (2014). In vitro cytotoxicity and antiviral efficacy against feline herpesvirus type 1 of famciclovir and its metabolites. Vet Ophthalmol. 17, 268-274.

29. Hamann M, Hill R, Roggo S, (2007). Marine natural products. Key advances to the practical application of this resource in drug development. Chimia. 61, 313-321.

30. Hammer KDP, Dietz J, Lo TS, Johnson ME, (2018). A systematic review on the efficacy of topical acyclovir, penciclovir, and docosanol for the treatment of herpes simplex labialis. EMJ Dermatol, 6, 118-123.

31. Hayashi N, Nakamuta M, Takehara T, Kumada H, Takase A, Howe AY, Ludmerer SW, Mobashery N, (2016). Vaniprevir plus peginterferon alfa- $2 b$ and ribavirin in treatment-naive Japanese patients with hepatitis $C$ virus genotype 1 infection: a randomized phase III study. Gastroenterology. 51, 390-403.

32. Hazuda DJ, Young SD, Guare JP, Anthony NJ, Gomez RP, Wai JS, Vacca JP, Handt L, Motzel SL, Klein HJ, Dornadula G, Danovich RM, Witmer MV, Wilson KA, Tussey L, Schleif WA, Gabryelski LS, Jin L, Miller MD, Casimiro DR, Emini EA, Shiver JW (2004). Integrase inhibitors and cellularimmunity suppress retroviral replication in rhesus macaques. Sci.305, 528-532.

33. Heim MH, (2013). 25 years of interferon-based treatment of chronic hepatitis $C$ : An epoch coming to an end. Nat Rev Immunol. 13, 535-542.

34. Hussein İTM, Menashy RV, Field HJ, (2008). Penciclovir is a potent inhibitor of feline herpesvirus-1 with susceptibility determined at the level of virus-encoded thymidine kinase. Antiviral Res. 3, 268-274.

35. Ikeda T, Tennyson R, Walker SN, Harris RS, McNaughton B (2019): Evolved Proteins Inhibit Entry of Enfuvirtide-
Resistant HIV-1, ACS Infect Dis (Article ASAP), DOI: 10.1021/acsinfecdis.8b00362.

36. Ison MG, (2013). Clinical use of approved influenza antivirals: therapy and prophylaxis. Influenza Other Respi Viruses. 7, 7-13.

37. Jacob A, Sood R, Chanu KV, Bhatia S, Khandia R, Pateriya AK, Nagarajan S, Dimri U, Kulkarni DD, (2016). Amantadine resistance among highly pathogenic avian influenza viruses (H5N1) isolated from India, Microb Pathog. 91, 35-40.

38. Kamali A, Holodniy M, (2013). Influenza treatment and prophylaxis with neuraminidase inhibitors: a review. İnfect Drug Resist. 6, 187-198.

39. Kozakov D, Chuang GY, Beglov D, Vajda S, (2010). Where does amantadine bind to the influenza virus M2 proton channel ?. Trends Biochem Sci. 35,471-475.

40. Lai CL, Gane E, Liaw YF, Hsu CW, Thongsawat S, Wang Y, Chen Y, Heathcote JE, Resenack J, Bzowej N, Naoumov NV, Di Bisceglie AM, Zeuzem S, Moon YM, Goodman Z, Chao G, Constance BF, Brown NA, (2007). Telbivudine versus Lamivudine in Patients with Chronic Hepatitis B. New Eng J Med. 357, 2576-2588.

41. Leung DT, Sacks SL, (2004). Docosanol: a topical antiviral for herpes labialis. Expert Opin Pharmacother. 5, 2567-2571.

42. Liang R, Li H, Swanson JM, Voth GA, (2014). Multiscale simulation reveals a multifaceted mechanism of proton permeation through the influenza A M2 proton channel. Proc Natl Acad Sci USA. 111, 9396-9401.

43. Lv Z, Chu Y, Wang Y, (2015). HIV protease inhibitors: a review of molecular selectivity and toxicity. HIV/AIDS (Auckl). 7, 95-104.

44. Maes R, (2012). Felid Herpesvirus Type 1 Infection in Cats. A Natural Host Model for Alphaherpesvirus Pathogenesis. Int Sch Res Net Vet Sci, 1-14.

45. Maggs DJ, (2005). Update on Pathogenesis, Diagnosis, and Treatment of Feline Herpesvirus Type 1, Clin Tech Small Anim Pract. 20, 94-101.

46. Maggs DJ, Clarke HE, (2004). In vitro efficacy of ganciclovir, cidofovir, penciclovir, foscarnet, idoxuridine, and acyclovir against feline herpesvirus type-1. Am J Vet Res. 65, 399-403.

47. Mahmoud S, Hasabelnaby S, Hammad SF, Sakr TM, (2018). Antiviral Nucleoside and Nucleotide Analogs: A Review. J Adv Pharm Res. 2, 73-88.

48. McKimm-Breschkin JL, (2013). Influenza neuraminidase inhibitors: antiviral action and mechanisms of resistance. İnfluenza Other Respir Virus. 7, 25-36.

49. Messina JP, Humphreys I, Flaxman A, Brown A, Cooke GS, Pybus OG, Barnes E, (2015). Global distribution and prevalence of hepatitis $C$ virus genotypes. Hepatology. 61, 77-87.

50. Moscana A, (2005). Neuraminidase Inhibitors for Influenza. New Eng J Med. 353, 1363-1373.

51. Mouscadet JF, Tchertanov L, (2009). Raltegravir: molecular basis of its mechanism of action. Eur J Med Res. 14, 5-16. 
52. Nováková L, Pavlík, J. Chrenková L, Martinec O, Červený L, (2018). Current antiviral drugs and their analysis in biological materials - Part I: Antivirals against respiratory and herpes viruses. J Pharm Biomed Anal. 147, 400-416.

53. Patel P, Louie S, (2018). Drug Interactions in HIV: Protease and Integrase Inhibitors. Pai M, Kiser J, Gubbins P, Rodvold $K$ eds. Drug Interactions in Infectious Diseases: Antimicrobial Drug Interactions Fourth edition. Humana Press, Cham. p.255-295.

54. Patel, IH, Zhang X, Nieforth K, Salgo M, Buss N, (2005). Pharmacokinetics, pharmacodynamics and drug interaction potential of enfuvirtide. Clin Pharmacokinet. 44, 175186.

55. Perry CM, (2010). A Review of its Use in the Management of CCR5-Tropic HIV-1 Infection. Drugs. 70, 1189-1213.

56. Pielak RM, Schnell JR, Chou JJ, (2009). Mechanism of drug inhibition and drug resistance of influenza A M2 channel, Proc Nat Acad Sci. 106, 7379-7384.

57. Poole CL, James SH, (2018). Antiviral therapies for herpesviruses: Current agents and new direction. Clin Thera. 40, 1282-1298.

58. Quashie PK, Sloan RD, Wainberg MA, (2012). Novel therapeutic strategies targeting HIV integrase. BMC Med. 10, $1-11$.

59. Rad TM, Saghaie L, Fassihi A, (2019). HIV-1 Entry Inhibitors: A Review of Experimental and Computational Studies. Chem Biodiversty. 15, e1800159.

60. Razonable RR, (2011). Antiviral Drugs for Viruses Other Than Human Immunodeficiency Virus. Mayo Clin Proc. 86, 1009-1026.

61. Rokx C, Rijnders BJA, (2015). Evidence gathered from randomized clinical trials and observational studies on the equivalence of emtricitabine and lamivudine. Clin Infect Dis. 60, 1732-1733

62. Sacks SL, Thisted RA, Jones TM, Barbarash RA, Mikolich DJ, Ruoff GE, Jorizzo JL, Gunnill LB, Katz DH, Khalil MH, Morrow PR, Yakatan GJ, Pope LE, Berg JE, Docosanol $10 \%$ Cream Study Group, (2001). Clinical efficacy of topical docosanol 10\% cream for herpes simplex labialis: a multicenter, randomized, placebo-controlled trial. J Am Acad Dermatol.45, 222-230.

63. Samson M, Pizzorno A, Abed Y, Boivin G, (2013). Influenza virus resistance to neuraminidase inhibitors. Antiviral Res. 98,174-185.

64. Sancho-Ruiz A, Sheldon J, Soriano V, (2007). Telbivudine: a new option fort he treatment of chronic hepatitis $B$. Expert Opin. Biol. Ther. 7, 751-761.

65. Sandmeyer LS, Keller CB, Bienzle D, (2005). Effects of interferon- $\alpha$ on cytopathic changes and titers for feline her- pesvirus-1 in primary cultures of feline corneal epithelial cells. Am J Vet Res. 66, 210-216.

66. Sarrazin C, (2016). The importance of resistance to direct antiviral drugs in $H C V$ infection in clinical practice. $\mathrm{J}$ Hepatol. 64, 486-504.

67. Schoggins JW, (2018). Recent advances in antiviral interferon-stimulated gene biology. F1000Research. 7: 309. Erişim tarihi: 28.03.2019.

68. Sebbag L, Thomasy SM, Woodward PA, Heather KK, Maggs DJ, (2016). Pharmacokinetic modeling of penciclovir and BRL42359 in the plasma and tears of healthy cats to optimize dosage recommendations for oral administration of famciclovir. Am J Vet Res. 77, 833-845.

69. Segovia CM, Chacra W, Gordon SC, (2012). Adefovir dipivoxil in chronic hepatitis B: history and current uses. Expert Opin Pharmacother. 13, 245-254.

70. Seley-Radtke KL, Yates MK, (2018). The evolution of nucleoside analogue antivirals: A review for chemists and non-chemists. Part 1: Early structural modifications to the nucleoside scaffold. Antivir Res. 154, 66-86.

71. Siebeck N, Hurley JD, Garcia M, Greene CE, Köstlin RG, Moore AP, Dietrich UM, (2006). Effects of human recombinant alpha-2b interferon and feline recombinant omega interferon on in vitro replication of feline herpesvirus-1. Am J of Vet Res. 8, 1406-1411.

72. Tan Q, Zhu Y, Li J, Chen Z, Han GW, Kufareva I, Li T, Ma L, Fenalti G, Li J, Zhang W, Xie X, Yang H, Jiang H, Cherezov V, Liu H, Stevens RC, Zhao Q, Wu B, (2013). Structure of the CCR5 Chemokine Receptor-HIV Entry Inhibitor Maraviroc Complex. Sci. 341, 1387-1390.

73. Thomasy SM, Maggs DJ, (2016). A review of antiviral drugs and other compounds with activity against feline herpesvirus type 1. Vet Ophthalmol. 19, 119-130.

74. Tözsér J, (2010). Comparative Studies on Retroviral Proteases: Substrate Specificity. Viruses. 2, 147-165.

75. Wensing AM, Van Maarseveen NM, Nijhuis M, (2010). Fifteen years of HIV protease inhibitors: raising the barrier to resistance. Antiviral Res. 85, 59-74.

76. Wilhelmus KR, (2015). Antiviral treatment and other therapeutic interventions for herpes simplex virus epithelial keratitis. Cochrane Database Syst Rev, 8, CD002898.

77. Yamada H, İkushima İ, Nemato T, İshikawa T, Ninomiya $\mathrm{N}$, İie S, (2017). Effects of a nutritional protein-rich drink on the pharmacokinetics of elvitegravir, cobicistat, emtricitabine, tenofovir alafenamide, and tenofovir compared with a standard meal in healthy japanese male subjects. Clin Pharma Drug Develop. 7, 132-142. 